\title{
Keanekaragaman Jenis Ikan di Hilir Sungai Sekadau Kalimantan Barat
}

\author{
Kristoforus Slamet Suryadi ${ }^{1}$, Junardi $^{1}$, Tri Rima Setyawati ${ }^{1}$ \\ ${ }^{1}$ Program Studi Biologi, Fakultas MIPA, Universitas Tanjungpura, JL. Prof. Dr. H. Hadari Nawawi, Pontianak \\ Email korespondensi: kristoforusslametsuryadi03724@gmail.com
}

\begin{abstract}
Diversity of fish species is important known to determinate river. The purpose of this study was to determine the diversity and distribution of fish also environmental conditions in the lower reaches of the Sekadau River, West Kalimantan. Data collection is conducted from March to May 2018 using posat and gill net. The results showed that the most common Cyprinidae family was found in Rasbora argyrotaenia and Osteochilus microcephalus with dominance value 0.72 and 0.70 respectively.
\end{abstract}

Keywords: Cyprinidae, Diversity, Osteochilus microcephalus, Rasbora argyrotaenia, Sekadau River

\section{PENDAHULUAN}

Sungai Sekadau merupakan sungai terpanjang di Kabupaten Sekadau dengan panjang \pm 117 kilometer dengan lebar 80-150 meter (BPS, 2018).

Aktivitas yang dilakukan masyarakat di sekitar dan di hulu sungai, seperti adanya penambangan pasir, pembukaan lahan untuk pemukiman penduduk, perkebunan sawit, dan aktivitas penyeberangan kapal motor secara langsung maupun tidak langsung akan mengganggu keseimbangan ekosistem sungai. Ekosistem sungai yang terganggu akan berdampak juga pada keseimbangan biota termasuk ikan.

Produksi ikan setelah adanya penambangan pasir mengalami penurunan sebanyak $60,86 \%$ (Trisnani, 2011). Pembukaan lahan perkebunan kelapa sawit berdampak pada penurunan produksi ikan yang disebabkan oleh penurunan kualitas air akibat limbah hasil pengolahan kelapa sawit (Handayani, 2015). Tujuan dari penelitian ini mengetahui keanekaragaman dan distribusi ikan serta kondisi faktor lingkungan di Hilir Sungai Sekadau

\section{BAHAN DAN METODE}

\section{Waktu dan Tempat Penelitian}

Penelitian dilaksanakan selama 3 bulan, mulai dari bulan Maret hingga Mei 2018. Penelitian dilakukan di Hilir Sungai Sekadau, Kecamatan Sekadau Hilir,
Kabupaten Sekadau, Kalimantan Barat. Identifikasi jenis ikan dilakukan di lapangan dan di Laboratorium Zoologi Fakultas Matematika dan Ilmu Pengetahuan Alam Universitas Tanjungpura Pontianak.

\begin{abstract}
Alat dan Bahan
Alat - alat yang digunakan dalam penelitian ini adalah adalah jaring insang (gill net) ukuran 2 inchi,posat (jaring angkat tradisional), coolbox, GPS GARMIN Etrex 30, kamera, gunting, plastik packing, number tagging, mistar, pinset, serokan, ember, termometer, keping sechi, stopwatch, meteran, bola pimpong, kertas $\mathrm{pH}$, kertas label, botol film, botol Winkler dan Erlenmeyer. Bahanbahan yang digunakan dalam penelitian ini adalah alkohol 70\%, akuades, formalin 10\%, kalium hidroksida-kalium iodide (KOH-KI), mangan sulfat $\left(\mathrm{MnSO}_{4}\right)$, asam sulfat $\left(\mathrm{H}_{2} \mathrm{SO}_{4}\right)$ pekat, indikator amilum $0,5 \%$, indikator fenolftalein (PP), natrium karbonat $\left(\mathrm{Na}_{2} \mathrm{CO}_{3}\right) 0,01 \mathrm{~N}$ dan natrium tiosulfat $\left(\mathrm{Na}_{2} \mathrm{SO}_{3}\right) 0,023 \mathrm{~N}$.
\end{abstract}

\section{Metode Penelitian}

Stasiun penelitian ini ditentukan berdasarkan perbedaan rona lingkungan yang berbeda. Berdasarkan hasil survei awal ditetapkan 4 stasiun penelitian pengambilan sampel ikan di hilir Sungai Sekadau, Kabupaten Sekadau. Stasiun penelitian dideskripsikan pada Tabel 1 dan peta lokasi dapat dilihat pada gambar 1 
Protobiont (2019) Vol. 8 (2) : 82 - 87

Tabel 1. Lokasi Habitat Stasiun Penelitian

\begin{tabular}{|c|c|c|}
\hline Stasiun & Titik Koordinat & Vegetasi dan Rona Lingkungan \\
\hline I & $\begin{array}{l}00^{\circ} 01 ' 30.4 ” \text { LU } \\
110^{\circ} 533^{\prime} 33.9 \text { 'BT }\end{array}$ & $\begin{array}{l}\text { Berada paling dekat dengan pertemuan arus Sungai Sekadau dan } \\
\text { Sungai Kapuas dengan substrat berupa pasir berlumpur dan terdapat } \\
\text { pemukiman penduduk di kanan dan kiri Sungai. }\end{array}$ \\
\hline 2 & $\begin{array}{l}00^{\circ} 01 ' 21.4 " \text { LU } \\
110^{\circ} 533^{\prime} 43.7 ' \mathrm{BT}\end{array}$ & $\begin{array}{l}\text { Berada di dekat anak sungai, substrat dasarnya berupa pasir dan } \\
\text { sedikit berlumpur dengan aliran air yang tenang dengan pepohonan } \\
\text { durian dan perkebunan karet dipinggiran sungai. }\end{array}$ \\
\hline 3 & $\begin{array}{l}00^{\circ} 01^{\prime} 07.1 ’ \mathrm{LU} \\
110^{\circ} 54^{\prime} 32.3{ }^{\prime \prime} \mathrm{BT}\end{array}$ & $\begin{array}{l}\text { Berada di dekat area pertambangan pasir dengan substrat dasar berupa } \\
\text { pasir. }\end{array}$ \\
\hline 4 & $\begin{array}{l}01^{\circ} 01^{\prime} 30.8 ’ \mathrm{LU} \\
110^{\circ} 544^{\prime} 31.8 ’ \mathrm{BT}\end{array}$ & $\begin{array}{l}\text { Berada di dekat Jembatan Penanjung dengan substrat berupa bebatuan } \\
\text { dan di temukan beberapa lanting diatas sungai. }\end{array}$ \\
\hline
\end{tabular}

Keterangan : BT (Bujur Timur) dan LU (Lintang Utara)

Pengambilan sampel ikan di setiap stasiun dilakukan selama 3 minggu dengan intensitas 1 minggu sekali menggunakan ukuran jaring insang (panjang $20 \mathrm{~m}$ dan lebar $2 \mathrm{~m}$ dengan ukuran mata jaring $2 \mathrm{~cm}$ ) dan alat tangkap tradisional berupa posat. Jaring insang dipasang mulai pukul 06.00 WIB dan diangkat kembali setiap 4 jam sekali sehingga ikan yang terperangkap tidak mati. Posat dipasang pada saat pagi hari dengan cara ditenggelamkan dan diangkat setiap 30 menit. Ikan hasil tangkapan yang diperoleh dicuci dengan air bersih kemudian didokumentasi dan diawetan dengan larutan formalin 10\%. Sampel yang sudah disuntik dimasukan ke dalam wadah tertutup yang berisi formalin $10 \%$. Sampel ikan kemudian dipindahkan ke dalam toples berisi larutan alkohol 70\% (Roberts 1989; Kottelat et al.,1993).

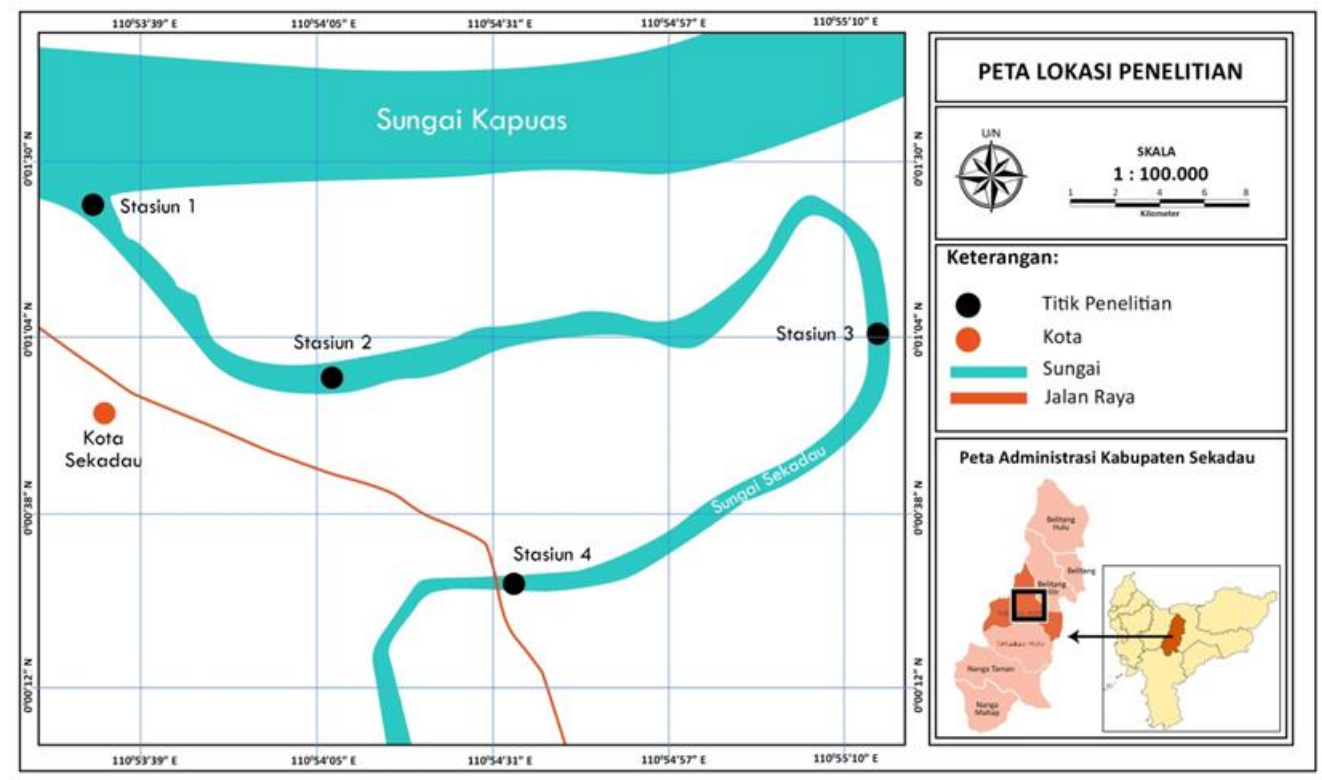

Gambar 1. Peta Stasiun Penelitian berdasarkan Mapsource 2018 
Pengukuran kondisi fisika dan kimia perairan meliputi kedalaman, kecerahan, suhu, $\mathrm{pH}$, kecepatan arus, $\mathrm{CO}_{2}$, dan DO dilakukan sebanyak tiga kali yaitu pada waktu pagi, siang, serta sore hari dan diulang selama 3 kali.

HASIL DAN PEMBAHASAN

Tabel 2. Komposisi jenis ikan yang terdapat pada hilir Sungai Sekadau Kabupaten Sekadau

\begin{tabular}{|c|c|c|c|c|c|c|c|c|}
\hline \multirow{2}{*}{ Taksa } & \multirow{2}{*}{ Nama lokal } & \multicolumn{4}{|c|}{ Total } & \multirow{2}{*}{$\begin{array}{c}\mathrm{K} \\
\left(\mathrm{Ind} / \mathrm{m}^{2)}\right.\end{array}$} & \multirow{2}{*}{$\begin{array}{l}\mathrm{KR} \\
(\%)\end{array}$} & \multirow{2}{*}{$\begin{array}{l}\text { FK } \\
(\%)\end{array}$} \\
\hline & & SI & SII & SIII & SIV & & & \\
\hline \multicolumn{9}{|l|}{ Bagridae } \\
\hline 1. Mystus singaringan*, & Patik & 2 & - & - & - & 0,050 & 0,77 & 25 \\
\hline \multicolumn{9}{|l|}{ Cyprinidae } \\
\hline 1. Barbodes schwanfeldii*, & Tengadak & - & 1 & 1 & 3 & 0,100 & 1,54 & 50 \\
\hline 2. Cyprinella spiloptera*' & Bantak padi & - & 1 & $\overline{-}$ & - & 0,025 & 0,38 & 25 \\
\hline 3. Desmopuntius johorensis*' & Bantak batu & 1 & 2 & 2 & - & 0,125 & 1,93 & 75 \\
\hline 4. Labeo chrysophekadion*' & Kelabau hitam & - & & & 1 & 0,025 & 0,38 & 25 \\
\hline 5. Labiobarbus sp. ${ }^{*}$ & Bantak & 2 & - & - & 1 & 0,075 & 1,15 & 50 \\
\hline 6. L. leptocheilus*' & Emporas & - & 2 & 1 & - & 0,025 & 0,38 & 25 \\
\hline 7. L. lineatus & Parau & i & 3 & 1 & - & 0,100 & $\begin{array}{l}1,53 \\
020\end{array}$ & 50 \\
\hline 8. Osteochilus melanopleurus*' & Kelabau & $\begin{array}{l}1 \\
0\end{array}$ & 4 & 2 & 7 & 0,025 & 0,38 & 25 \\
\hline 9. O. microcephalus* & Bantak & 8 & 4 & 3 & 7 & 0,550 & 8,46 & 100 \\
\hline 10. Rasbora argyrotaenia*” & Seluang & 4 & 60 & 40 & 60 & 53,25 & 81,92 & 100 \\
\hline Siluridae & & & 2 & 2 & - & 0,075 & 1,15 & 50 \\
\hline 1. Kryptopterus limpok*' & Lais & & & & & & & \\
\hline
\end{tabular}

Keterangan: (S I-IV) Stasiun I-IV (*) Paling Sedikit dan (**) Paling Banyak, Jenis (*') Alat Tangkap Pukat dan (*”) Alat Tangkap Posat

Dilihat dari komposisi ikan-ikan yang ditemukan, kawasan Hilir Sungai Sekadau memiliki kelimpahan dan frekuensi yang berbeda-beda pada setiap habitatnya. Frekuensi tertinggi terdapat pada Rasbora argyrotaenia dan Osteochilus microcephalus dengan frekuensi kehadiran $100 \%$

\section{Keanekaragaman Jenis Ikan}

Keanekaragaman jenis $(\mathrm{H})$ ikan yang terdapat di setiap stasiun di Hilir Sungai Sekadau rendah

\section{Komposisi Jenis}

Penelitian ini berhasil menemukan 12 jenis ikan yang termasuk ke dalam tiga famili, yaitu: Cyprinidae (10 jenis), Siluridae (satu jenis) dan Bagridae (satu jenis). Komposisi ikan yang ditemukan disajikan pada Tabel 2.

Tabel 3. Keanekaragaman Jenis Ikan Di Hilir Sungai Sekadau Kecamatan Sekadau Hilir Kabupaten

\begin{tabular}{cccc}
\hline Stasiun & $\mathrm{H}^{\prime}$ & $\mathrm{E}^{\prime}$ & $\mathrm{C}^{\prime}$ \\
\hline I & $0,36^{*}$ & $0,49^{*}$ & $0,61^{* *}$ \\
II & 0,29 & $0,36^{* *}$ & $0,72^{*}$ \\
III & 0,33 & 0,39 & 0,68 \\
IV & $0,27^{* *}$ & 0,39 & 0,70 \\
\hline
\end{tabular}

Keterangan: (H') Keanekaragaman, (E') Kemerataan, (C') Dominansi

$\left(\mathrm{H}^{\prime}<1\right)$. Keragaman jenis ikan yang relatif tinggi terdapat pada stasiun 1 sebesar 0,36 dan rendah pada stasiun 4 sebesar 0,27 . Kemerataan (E') jenis ikan yang relatif tinggi terdapat pada stasiun 1 sebesar 0,49 dan rendah pada stasiun 2 sebesar 0,36. Indeks dominansi (C') ikan antara 0,61-0,72. Dominansi jenis tertinggi ditemukan di stasiun 2 dan terendah di stasiun 1 (Tabel 3).

\section{Parameter Lingkungan}

Hasil pengamatan parameter lingkungan di Hilir Sungai Sekadau disajikan pada Tabel 4. Parameter lingkungan tersebut antara lain suhu, $\mathrm{pH}$, kecerahan, kedalaman, kecepatan arus, $\mathrm{CO}_{2}$ dan DO 
Protobiont (2019) Vol. 8 (2) : 82 - 87

Tabel 4. Hasil pengukuran faktor Fisika Kimia Air di Hilir Sungai Sekadau

\begin{tabular}{lrrrr}
\hline Parameter & Stasiun 1 & Stasiun 2 & Stasiun 3 & Stasiun 4 \\
\hline Suhu $(\mathrm{C})$ & 28 & 27,6 & 28 & 28 \\
$\mathrm{pH}$ & 5,50 & 5,63 & 5,54 & 5,43 \\
Kecerahan $(\mathrm{cm})$ & 89,1 & 63,8 & 91,8 & 72,8 \\
Kedalaman $(\mathrm{cm})$ & 420 & 385 & 340 & 223 \\
Kecepatan arus $(\mathrm{cm} / \mathrm{dt})$ & 10,5 & 8,8 & 10,4 & 10,7 \\
Oksigen terlarut $(\mathrm{mg} / \mathrm{L})$ & 5,72 & 6,12 & 4,98 & 5,62 \\
Karbondioksida $(\mathrm{mg} / \mathrm{L})$ & 2,33 & 2,53 & 2,14 & 2,37 \\
\hline
\end{tabular}

\section{Hasil Principal Components Analysis (PCA)}

Hasil Principal Components Analysis (PCA) menunjukkan bahwa tidak semua faktor lingkungan memengaruhi keragaman jenis, namun hanya ada beberapa jenis yang keberadaannya dipengaruhi oleh kondisi lingkungan di lokasi penelitian (gambar 2). Gambar tersebut menjelaskan hubungan antara indikator lingkungan yang diambil dengan keragaman jenis ikan di Hilir Sungai Sekadau. Analisis komponen utama pada sumbu satu dan dua (PC1 \& PC2) menunjukkan bahwa kontribusi kedua sumbu sebesar 43,2\% dan sisanya sebesar $31,9 \%$ total $75,1 \%$ dan sisanya termasuk dalam faktor galat (eror). Hasil analisis menunjukkan faktor lingkungan yang sangat berpengaruh terhadap keanekaragaman beberapa jenis ikan yang terdapat pada Hilir Sungai Sekadau adalah DO dan CO (gambar 2).

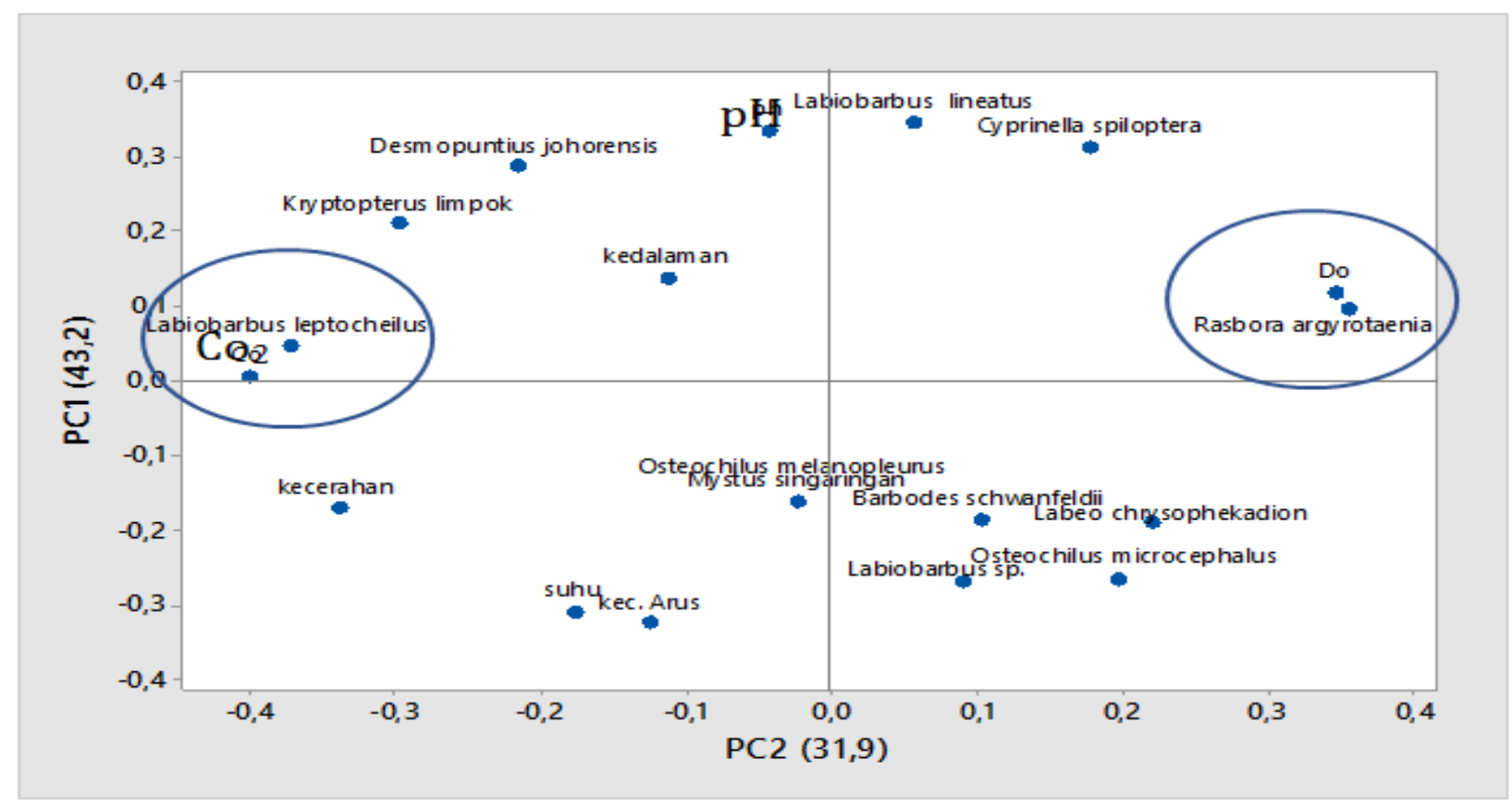

Gambar 2 Hasil Principal Components Analysis (PCA)

Jenis ikan yang didapat pada lokasi penelitian Sungai Sekadau bagian hilir Kabupaten Sekadau paling banyak pada famili Cyprinidae. Banyaknya jumlah jenis yang ditemukan pada famili tersebut karena anggota famili tersebut memiliki sebaran yang lebih luas dibandingkan dengan famili lainnya. Menurut Bishop (1973) komposisi ikan berubah sepanjang aliran. Faktor yang memengaruhi adalah kehadiran tumbuhan yang digunakan sebagai sumber penghasil oksigen yang diperoleh dari hasil fotosintesis yang dilepaskan ke dalam air, naungan memengaruhi suhu air, pasokan makanan dan distribusi arus dan lubuk.

Secara alami $R$. argyrotaenia hidup secara berkelompok di permukaan perairan hingga bagian tengah. Jenis $R$. argyrotaenia ditemukan di seluruh stasiun penangkapan. Ikan seluang sering ditemukan dalam kelompok pada saat berenang. 
Ikan ini juga ditemukan di sungai yang memiliki arus relatif lambat. Ciri morfologi ikan ini adalah pada batang ekornya dikelilingi 14 sisik, garis warna gelap memanjang dari operkulum sampai pangkal sirip ekor. Variasi bentuk badan dan warna pada jenis ini sangat beragam (Kottelat, et al., 1993). Jenis $R$. argyrotaenia suka berenang sampai permukaan air khususnya saat permukaan air sungai meningkat. Pada waktu seperti ini, $R$. argyrotaenia berenang ke permukaan untuk mencari makanan. Pada saat penelitian dilakukan permukaan air sungai sedang tinggi yang menyebabkan hasil yang diperoleh jenis $R$. argyrotaenia lebih banyak.

Jumlah jenis ikan yang paling sedikit didapatkan dalam penelitian ini adalah $C$. spiloptera, $L$. chrysophekadion, L. leptocheilus, $O$. melanopleurus masing-masing satu individu. Jenis ikan tersebut sedikit ditemukan karena keberadaan salah satunya dipengaruhi oleh ketinggian air. Pada saat penelitian sungai dalam keadaan pasang sehingga jenis tersebut lebih sulit untuk ditangkap. Kedalaman sungai pada saat penelitian pada kisaran $223-420 \mathrm{~cm}$. Jenis ikan dari famili Siluridae dan Bagridae ditemukan masing-masing satu Jenis. Jenis Kryptopterus limpok memiliki dua pasang sungut dengan sungut rahang atas mencapai sirip anal dengan warna badan mengkilap dengan bintik hitam secara menyeluruh dibagian dorsal. Jenis Kryptopterus limpok ditemukan pada stasiun 2 yang memiliki substrat berupa pasir berlumpur dengan suhu $27,6^{\circ} \mathrm{C}$ dengan kecerahan $63,8 \mathrm{~cm}$. Kondisi faktor lingkungan ini sangat memengaruhi keberadaan jenis ikan dari famili siluridae. Menurut Wardoyo (1981) suhu optimum ikan famili siluridae berkisar antara $25-30{ }^{\circ} \mathrm{C}$ dengan warna perairan yang tidak keruh.

Jenis ikan famili bagridae ditemukan satu jenis yaitu Mystus singaringan dengan ciri morfologi memiliki sirip lemak yang panjang, sungut rahang atas sangat panjang dan mencapai pangkal sirip caudal. Ikan ini ditemukan pada stasiun satu yang berada di muara sungai dengan substrat dasar berupa pasir berlumpur dengan kedalaman mencapai $420 \mathrm{~cm}$.

Kawasan Hilir Sungai Sekadau memiliki kelimpahan dan frekuensi yang berbeda-beda pada setiap habitatnya. Frekuensi tertinggi terdapat pada jenis ikan $R$. argyrotaenia dan $O$. microcephalus dengan frekuensi kehadiran ikan dengan nilai $100 \%$ ditemukan pada setiap stasiun. Kedua jenis jenis ini memiliki frekuensi kehadiran sangat tinggi terutama pada jenis $R$. argyrotaenia yang dijumpai di setiap stasiun dan dalam jumlah yang lebih banyak.

Frekuensi kehadiran jenis ikan yang didapat paling rendah $C$. spiloptera, L. chrysophekadion, $L$. leptocheilus, O. melanopleurus. Keempat jenis ini frekuensi kehadirannya sangat rendah hanya pada satu stasiun. Keempat jenis ini menempati habitat berpasir dengan aliran air yang tenang. Keanekaragaman jenis ikan yang terdapat pada setiap stasiun di Hilir Sungai Sekadau relatif rendah $H^{\prime}<1$. Keragaman jenis ikan tertinggi terdapat pada stasiun 1 sebesar 0,36 Keragaman jenis ikan terendah terdapat pada stasiun 4 sebesar 0,27. Keragaman jenis ikan dihilir sungai Sekadau relatif rendah disebabkan oleh jenis-jenis ikan yang diperoleh tidak terlalu banyak. Kondisi keragaman jenis ikan yang rendah dapat disebabkan oleh kondisi vegetasi lingkungan yang sudah tidak baik seperti penambangan pasir yang dapat menyebabkan perubahan struktur sungai serta menyebabkan kekeruhan pada air sungai.

Komunitas ikan air tawar bergantung pada kondisi hutan, karena detritus tumbuhan yang berasal dari vegetasi hutan ditepi sungai merupakan sumber makanan penting untuk sebagian besar ikan. Suhu air meningkat karena naungan menjadi hilang, sehingga terjadi kenaikan suhu air akibat hutan yang rusak. Konsentrasi oksigen terlarut di dalam air juga menurun. Stasiun 2 memiliki suhu terendah sebesar $27,6^{\circ} \mathrm{C}$ dikarenakan pada tepi sungai dikelilingi oleh perkebunan karet dan durian sedangkan pada stasiun lain tepi sungai lebih terbuka sehingga suhu air lebih tinggi. Semakin tinggi suhu air, maka laju metabolisme ikan juga meningkat akan berakibat terjadi kenaikan suhu, sehingga oksigen yang dibutuhkan akan semakin tinggi (Mackinnon et al., 2000). Kecerahan air dipengaruhi oleh aktivitas di hulu sungai. Kekeruhan air membatasi penetrasi cahaya ke dalam air yang berfungsi membantu proses fotosintesis tumbuhan air (Ang, 1984).

Hasil Analisis PCA menunjukan bahwa faktor yang paling berpengaruh terhadap kelimpahan jenis ikan di Hilir Sungai Sekadau adalah DO. Jenis ikan yang sangat dipengaruhi oleh parameter DO adalah $R$. argyrotaenia. Hal ini ditunjukan oleh titik koordinat keduanya yang saling berdekatan. Oksigen terlarut dalam air dimanfaatkan untuk proses respirasi yang menghasilkan energi untuk pertumbuhan dan pembiakan (Odum,1993). Ikan seluang bersifat omnivora. Makanannya dapat beragam mulai dari zooplankton, lumut, crustacea kecil (seperti kutu air), telur ikan hingga cacing tanah (Azrita, 2012) 
Faktor lingkungan lainnya yang juga berpengaruh terhadap kelimpahan adalah $\mathrm{CO}_{2}$. Kelimpahan ikan yang terkait dengan parameter ini adalah Labiobarbus leptocheilus. Konsentrasi $\mathrm{CO}_{2}$ dalam air berperan memengaruhi laju proses fotosintesis pada fitoplankton. Fitoplankton merupakan makanan bagi ikan L. leptocheilus (Kusumasari, 2007).

Kehidupan dalam air juga terdapat siklus rantai makanan. Semua unsur dalam air memengaruhi kehidupan mahluk hidup. Unsur-unsur yang terdapat di dalam air harus sesuai agar kehidupan di dalamnya lebih seimbang. Faktor lingkungan memengaruhi keragaman jenis ikan. Penelitian ini mendapatkan bahwa faktor yang paling memengaruhi kelimpahan jenis ikan adalah DO dan $\mathrm{CO}_{2}$.

Konsentrasi oksigen terlarut di sungai ditentukan oleh kombinasi faktor fisika,kimia dan biologi. Suhu perairan dipengaruhi aliran sungai. Suhu air di tempat-tempat ternaungi lebih rendah dibandingkan sungai dengan kondisi terbuka. Semua faktor fisika dan kimia tersebut akan memengaruhi keragaman ikan di dalam komunitas sungai. Ikan yang terdapat di perairan tawar sangat bergantung pada kualitas air. Ikan dapat berguna bagi indikator biologi untuk keadaan lingkungan karena berada dalam rantai makanan dan sangat rentan terhadap kontaminan dan gangguan (Kottelat et al., 1993)

\section{DAFTAR PUSTAKA}

Ang, 1984, Penyediaan Air Bersih, Proyek Pengembangan Pendidikan Tenaga Sanitasi Pusat Pendidikan dan Latihan Pegawai Departemen Kesehatan RI

Azrita, 2012, Fekunditas, Diameter Telur, dan Makanan Ikan Bujuk Pada Habitat Perairan Berbeda, Jurnal Riset Akuakultur, 7(3):381-392

Bishop, W, F, 1980, Structure, Stratigraphy, And Hydrocarbons Offshore Southern Kalimantan, Indonesia, American Association of Petroleum Geologists Bulletin, 64(1) : 7-58

BPS, 2018, Sekadau Dalam Angka, Badan Pusat Statistik Kabupaten Sekadau, Sekadau, Kalimantan Barat

Hidayani, 2015, Dampak Industri Pertanian Kelapa Sawit Terhadap Berkurangnya Ikan Di Perairan dan Flora serta fauna, Skripsi Politeknik Negeri Payakumbuh, Sulawesi Utara

Kottelat, M, Wittern, AJ, Kartika, SNS \& Wirjoatmodjo, S, 1993, Fresh Water Fishes Of Indonesia and
Sulawesi. Periplus Plus Edition Limited, Indonesia

Kusumasari, 2007, Biologi Reproduksi dan Kebiasaan Makanan Ikan (Labiobarbus leptocheilus) di Sungai Musi, Sumatera Selatan, Skripsi Institut Pertanian Bogor. Bogor

Mackinnon, K., 2000, Ekologi Kalimantan, alih bahasa Gembong Tjitrosoepomo, Prenhallindo, Jakarta

Odum, EP, 1996, Dasar - Dasar Ekologi, Edisi Ketiga, Gadjah Mada University Prees, Yogyakarta

Roberts, TR. 1989, The Fresh Water Fishes of Western Borneo (Kalimantan Barat, Indonesia), Memoirs of the California Academy of Sciences 14:1-210

Trisnani, 2011, Dampak Penambangan Pasir Terhadap Pendapatan Nelayan Di Kelurahan Kotalama Kecamatan Kunto Darussalam Kabupaten Rokan Hulu, Provinsi Riau, Skripsi Universitas Riau, Riau.

Wardoyo, S,1981, Kriteria Kualitas Air Untuk Keperluan Pertanian dan Perkebunan, ANDAL, United Nation Development Project. IPB, Bogor. 